\title{
When the Animal is the Therapist: Interspecies Practices in Human Care
}

\author{
Ivana Teixeira ${ }^{7}$ \\ ' Departamento de Saúde Coletiva, Universidade Federal do Rio Grande do Sul (UFRGS), \\ Porto Alegre/RS, Brasil
}

\begin{abstract}
The present article deals with the technical dimensions of zootherapy, focusing on the practices developed in this field in order to prepare the animal and the abilities already present in the animals themselves. Employing ethnographically-grounded data and focusing on the interactions between beings and the effects of these interactions, as observed and reported, we will discuss the works of Georges Haudricourt and Carole Ferret. We will then look at the potential and limits of the models presented by these two researchers, broadening the debate with the help of anthropology, by looking at the agency of the non-human beings involved in these practices (practices which seek to control many different processes). Finally, we will demonstrate that while zootherapy presents something of an enigma from the point of view of communications theory, it involves and highlights a series of actions that are socially learned by both humans and animals. In conclusion, we will consider some of the effects that this process has on humans.
\end{abstract}

Key words: Technical anthropology; actions; therapeutic processes; human-animal interactions; zootherapy. 


\section{Quando o animal é o terapeuta: práticas interespecíficas de cuidado humano}

\section{Resumo}

A partir da construção do processo terapêutico conduzido através da Zooterapia o artigo trata da dimensão técnica desta prática objetivando as ações que são desenvolvidas para preparar o animal assim como as habilidades presentes nos animais. Contando com um conjunto de dados etnograficamente fundamentados e centrados na prática a respeito da interação entre os seres e dos efeitos observados e relatados, serão trazidas à discussão duas proposições a respeito da técnica, o trabalho de André Georges Haudricourt e a abordagem de Carole Ferret. Em seguida, trata se dos potenciais e limites dos modelos expostos ampliando esse debate com a ajuda de proposições em antropologia que consideram a agência de não humanos nas práticas que tentam controlar os mais diversos processos. Por fim, apoiando se nas considerações anteriores, indica se que embora a zooterapia apresente algo enigmático do ponto de vista comunicacional, ela deixa aparecer uma série de ações socialmente aprendidas tanto pelo homem quanto pelos animais e algumas considerações a respeito dos efeitos que a técnica provoca no homem, são levantadas.

Palavras-chave: Antropologia da Técnica; Ações; Processo Terapêutico; Interação Homem-Animal; Zooterapia. 


\title{
When the Animal is the Therapist: Interspecies Practices in Human Care
}

\author{
Ivana Teixeira
}

\section{Introduction}

The question the present article deals with are the practices and relational horizons that cross-cut contemporary social dynamics, most particularly the therapeutic techniques developed by societies which aim at the recovery of good human health. More precisely, two propositions are described and analyzed in the following article regarding therapeutic techniques that insert living, active animals into the equipment and technology of the Western health system. Looking at this allows us to see other contours of the contemporary world regarding the relationship between nature-culture and man-animal, as well as certain questions in the field of biomedical knowledge. During the field work related to this project, carried out at various Zootherapy Associations ${ }^{1}$, I noticed that this activity allows us to objectify some of the mechanisms upon which therapeutic efficacy is based, clarifying the role of animals in healing or care processes. I will conclude by considering what changes zootherapeutic processes provokes in both animals and humans. Contextually, the politicalsocial scene in which these techniques are developed is set in the urban spaces of large cities which have seen an exponential increase in cases of mental illnesses such as depression, Alzheimer's disease, autism, and schizophrenia. It is also framed by the therapeutic limits of biomedicine, the limited means of treatment of certain diseases, the communicative limits of mankind, and the emergence of other types of relationships with nature.

Furthermore, given that the therapeutic component involved in these treatments is not a substance produced by the animal or located in a part of an animal's body that will be used as medicine ${ }^{2}$, something other than the mere cataloguing of animal substances is currently occurring in medicine. Zootherapeutic techniques involve using the animal in its entirety in order to intervene in processes of human life. Technically defined as the use of animals trained by health professionals (who themselves are trained through various social processes) in order to achieve specific measurable and documented progress for individual patients, the zootherapeutic animal as mediator, co-adjutant, or therapist is (literally) a completely different beast from those animals trained for other medical activities, such as service animals who guide people with reduced mobility. A pet dog can be used in physiotherapy, for example, for a patient who is seeking to improve their range of movement by causing the patient to throw a ball, which the dog recovers. Apparently, however, the physiological and psychological changes linked to the sustained positive therapeutic effects arising from human/animal interactions are not quite as clear or concrete in the field of mental health. Sometimes, the benefit of animals in these situations may be that of a "social mediator", which allows the patient to feel more comfortable and, consequently, more able to develop a therapeutic relationship with a human therapist.

\footnotetext{
Research carried out between 2011-2013 in the cities of Porto Alegre, São Paulo, and Rio de Janeiro and from 2014-2015 in France.

The theme of animals as a therapeutic resource is the most present research agenda in that field of biology which is concerned with identifying different animal species and their handling, particularly in ethnomedicine: the practices of riverine, indigenous, quilombola or metropolitan communities, under research principally in Central and Latin America (Mussolini, 1946; Araújo, 1977; Costa Neto, 1999; Alves and Dias, 2010 ; Machkour-M’Rabet et al., 2011), Africa (Soewu, 2013) and Asia (Kang et Phipps, 2003; Mohawar and Jaroli, 2008; Dixit et al., 2010). In animal mediation zootherapy, the species most commonly employed are dogs, horses, rabbits, birds (calopsite, parrot, parakeet and caturrita), guinea pigs, goats, some fish, snails, dolphins and -- more rarely - reptiles, such as iguanas.
} 
Given the determinants of zootherapy, as they are described below, some fundamental actions of this activity were observed, such as the general process that animals must pass through in order to become therapists, as well as the actions and skill sets that they can develop and perform. Based on this, I suggest that these actions are producers of therapeutic efficacy. For this purpose, my argument will be developed along two theoretical lines. The first employs the work of André-Georges Haudricourt $(1962,1987)$ and Carole Ferret $(2006,2012,2014)$ regarding the categorization of actions developed by man towards nature, and the theoretical positions of which have uses and limitations when applied to zootherapy. The second explores the potential of the concept of Passive Action (Ferret, 2012), through an analysis that looks at the exchanges between animals and patients and, more precisely, describes the gestures and abilities of the animals in question, in order to demonstrate a chain of events.

\section{Zootherapy as a technical skill}

When observing zootherapy sessions, two instances of the technical relationship involved in these stood out to me. The first takes into account the logic of production: in other words, the management of an animal in such a way as to make it "good for therapy" (training, sanitation and social measures, etc.) The second takes into account procedural logic (the way people/patients relate to the technique) and, therefore, the chain of actions that occurs during the therapeutic session. These two dimensions may present different points of view when, first of all, they lead us to consider the actions that man develops towards the animal and, secondly, they allow us to take understand the therapeutic moment through the actions that animals develop toward humans. Although these two dimensions are more of an analytical resource than two separate instances in real life, it is possible to observe a technical process exists that is composed of these two types of actions, in which humans and animals internalize technical behavior.

Behaviors that are understood as socially determined and expressed in embodied choices are, as Marcel Mauss taught us, a technical fact. In other words, they relate the body to the social realm: "the body is the first and most natural instrument of man" (Mauss, 2003: 407). This notion that the body carries traces of culture that are expressed in gestures and ways of doing things influenced several researchers in the early twentieth century, among them Mauss' disciples André-Georges Haudricourt (1911-1996) and André Leroi-Gourhan (1911-1986), who insisted upon observing the "concrete" linguistic and technical aspects of behavior, their relationships to the "social" and thus to larger social "mentalities". Leroi-Gourhan (1964) emphasized (as Mauss had already pointed out) that it was necessary to describe the manufacturing process, for example, as a technically linked set of activities (Leroi-Gourhan, 1964: 18) where technique was subjugated to matter, and not the other way round. The chief intellectual of what was to become known as the theory of the "operational sequence»3 in the field of analysis of prehistoric objects, Leroi-Gourhan had an enormous influence upon his colleague, André-Georges Haudricourt. Concerned about understanding technique as an activity, Haudricourt believed that technical objects cannot be separated from the operational sequence to which they are associated (1962: 41). In other words, he claims that technical facts can be analyzed through the lens of abilities that individuals acquire or have and that are present in function of the technique itself.

The main problem for Haudricourt was therefore to create a system of recording gestures which would enable us to establish a genealogical relationship that could account for a historic process. As Bechelany (2012: 249) points out, Haudricourt does not start by analyzing objects, but by looking at "the motor that makes

3 The operational sequence concept seeks to attribute meaning to an object in the sense that an object reveals its entire history. In this sense and in the same way, it transforms that which is static in the eyes of the researcher, turning it into something that has lasted to the present moment as a carrier of information regarding relations betweem subject and object, subject and subject, subject and environment and even object and object (Galhardo et al., 2015:12). 
the tool effective". The Haudricourt technique is inseparable from the manipulations that are influenced by a given activity as its developed in its ecological and social dimensions.

In Haudricourt'a article "Domestication des animaux, culture des plantes et traitement d'autrui", originally published in L'Homme in 1962, one sees a correspondence between the treatment of nature and the treatment of the other in, of all things, differences noted in the production of yams in Oceania and the rearing of ewes in the Mediterranean (Haudricourt, 1964). In this oft-quoted article and in a second, perhaps more illuminating text, André-Georges Haudricourt postulates the predominance, within each given society, of a certain type of action, both with regards to the treatment of nature and the treatment of other humans, opposing the agricultural techniques of yam cultivation and pastoral techniques as archetypes of two different models for action. He defines direct and positive action as represented in the art breeding sheep. This is qualified as direct because it exhibits a physical or permanent interrelationship between man and nature/the other. Negative indirect action is represented in the actions that man takes in the environment that surrounds the object, such as in yam cultivation. Although Haudricourt considered that different animal species would provoke different performances, these collectively remained in a model that proposes a bilateral division of the world in direct positive and indirect negative relationships.

Without necessarily accepting all of Haudricourt's arguments, Carole Ferret (2006), emphasizes that the analysis of concrete actions, whether in relation to objects or to the other, must consider that "actions exercised over a living being" are expressed not only in terms of "doing", but also, often in terms of "doing doing". She thus redraws the object that was once a sort of patient Haurdricout's theory, transforming it into an agent (Ferret, 2006: 22). Author of a large study horse-raising among the Yakoute in Siberia, Ferret employed an ethnography focused on the field of technique, dissociating the direct, indirect, negative and positive categories into three other dimensions of functionality, moving from passive action, where subjects abstain from doing, to interventionist action, which vigorously interferes the order of things and their becoming (Ferret, 2006, 2012: 134).

From this base, actions may be defined as endogenous (when the subject acts alone), exogenous (when it is aided by an external factor), and participant (when the object participates in the action). There is also a contrary form of action, consisting of exercising an action upon an "object-actor" (Ferret, 2012) in order to obtain a reaction contrary to the one stimulated. This would be the case, for example, of a rider who makes his horse march in zigzag fashion so that he learns to walk straight. And finally, Ferret stipulates that there are deleterious actions (which deteriorate an object), maintenance actions (which work towards an object's benefit), transformative actions (modifying the object) and neutral actions (having no effect on the object). The action of letting things go became known as passive action in Ferret's scheme, because "the subject (man) does nothing; or rather he does: he acts towards the object object by letting it take its own time"(Ferret, 2012: 126). This moment of "rest", where the subject is passive, is not simply stagnation because it can allow the object to transform. According to Ferret, this transformation can be caused by the object itself or by an exogenous factor such as time or changes in the environment (we will deal with this category further, below). The set of possible actions, as retuned by Carole Ferret, resulted in the following modalities: interventionist/active/passive action; endogenous/exogenous/participative action; direct/indirect action; positive/negative/contrary action; internal/ external action; a priori/a posteriori action; and continuous/discontinuous action.

4 An English version was published in L'Homme in 1969 (Haudricourt, 1969). The geographical scope of Haudricourt's research included two large areas: Mediterranean sheep herders and yam farmers in Oceania and here he established a relationship between the "pastoral" mode and the "horticultural" way of treating vegetables, animals and people. According to Haudricourt, the actions one observes in the pastoral mode are "à gouverner" and in the horticultural mode "à cultiver": direct and indirect actions, respectively (Haudricourt, 1962). The action of the shepherd on the sheep is constantly imposed in this model, since the domestication (or sub-domestication, as Haudricourt refers to it) of these animals relocates them in flat regions that are unlike their natural habitat (rocky mountains), making them susceptible to predators (wolves). On the other hand, the processes installed around the production of giant yams unfold via a contrary route -- that is, by virtue of the process of maturation and thinning of the yam. The yam demands of man actions that he must perform in order to protect the plant. 


\section{What makes an animal a therapist}

The process of forging a therapist out of an animal passes through different moments in which acts, physical values, and abilities are weighed in accordance with what it is desired that the animal do and be. Using Ferret's categories, we propose to objectify these steps. Looking at a process that involves different types of technologies. These range from the search for a certain adequate type of behavioral profile, to the observation of indicators of personality, to the training of skills. The stages delineated in the table below indicate how the animal is chosen, initial veterinary care, the use of certain artefacts, esthetic maintenance, and gestures that the animal must learn.

Tabela 1 - Main Actions Undertaken with regards to Dogs, Birds, and Rabbits

\begin{tabular}{|c|c|c|c|c|}
\hline Animal Type & Dog & Bird & Rabbit & $\begin{array}{c}\text { Typology of } \\
\text { Actions }\end{array}$ \\
\hline \multicolumn{5}{|l|}{$\begin{array}{c}\text { Principal } \\
\text { situations } \\
\text { involving human } \\
\text { intervention }\end{array}$} \\
\hline $\begin{array}{c}\text { 1 } \\
\text { Choosing the } \\
\text { animal }\end{array}$ & $\begin{array}{l}\text { Application of } \\
\text { Campbell Test }\end{array}$ & $\begin{array}{c}\text { Observation of } \\
\text { animal's appearance } \\
\text { or breed (breeder } \\
\text { certificate) }\end{array}$ & $\begin{array}{c}\text { Observation of } \\
\text { animal's appearance } \\
\text { or breed (breeder } \\
\text { certificate) }\end{array}$ & $\begin{array}{c}\text { Direct and } \\
\text { participative actions } \\
\text { External action } \\
\text { (choosing based on } \\
\text { animal's appearance) }\end{array}$ \\
\hline${ }^{2}$ Health check & $\begin{array}{l}\text { Vaccination, } \\
\text { castration, worming, } \\
\text { and anti-flea } \\
\text { medication }\end{array}$ & $\begin{array}{c}\text { Exams and worming } \\
\text { if necessary }\end{array}$ & $\begin{array}{c}\text { Castration, } \\
\text { worming, and } \\
\text { anti-flea medication } \\
\text { (for cats) }\end{array}$ & $\begin{array}{c}\text { Direct/external/ } \\
\text { internal/deleterious/ } \\
\text { contrary actions }\end{array}$ \\
\hline$\stackrel{3}{\text { Socialization }}$ & $\begin{array}{l}\text { Stay together with } \\
\text { the most experienced } \\
\text { animals in the } \\
\text { environment. From } \\
3 \text { months old on }\end{array}$ & $\begin{array}{l}\text { Stay together } \\
\text { with the most } \\
\text { experienced animals } \\
\text { in the environment. } \\
\text { From } 15 \text { days old on. }\end{array}$ & $\begin{array}{l}\text { Stay together with } \\
\text { the most experienced } \\
\text { animals in the } \\
\text { environment. From } \\
3 \text { months old on }\end{array}$ & $\begin{array}{c}\text { Exogenous/ } \\
\text { participative actions }\end{array}$ \\
\hline$\stackrel{4}{4}$ & Bath and grooming & Cutting of wings & $\begin{array}{l}\text { Bath, grooming, } \\
\text { naiol cutting }\end{array}$ & $\begin{array}{c}\text { Direct/ participative/ } \\
\text { deleterious/ } \\
\text { transformative actions }\end{array}$ \\
\hline $\begin{array}{c}5 \\
\text { Use of artefacts }\end{array}$ & $\begin{array}{l}\text { Use of leash, toy, } \\
\text { snack, or clicker }\end{array}$ & $\begin{array}{l}\text { Use of leash, } \\
\text { toy, or snack }\end{array}$ & Use of leash & $\begin{array}{l}\text { Direct/interventionist } \\
\text { actions }\end{array}$ \\
\hline
\end{tabular}

When it comes to dogs, animal selection seeks to evaluate the degree of a puppy's dominance in order to fit it into an ideal profile: the "dominance" trait must be tenuous, but present. This behavioral trait, common to individuals of various species, has a strong evolutionary importance for social species and, above all, for the man-dog relationship, which -- to a certain extent -- is based on dominance/submission (Kohn, 2016: 19). This characteristic is manifest in animals in a number of ways, that can be measured in tests with dog pups, such as the widely used Campbell Test (Campbell, 1972). The test is divided into five stages, each corresponding to a different operation undertaken with the puppy, where his response is evaluated and classified as very dominant, dominant, submissive, very submissive, or independent/fearful. The test is divided into the following steps: Social Attraction, Examiner Tracking, Containment, Social Dominance, and High Dynamics, each of which has characteristic operations. In Social Attraction, for example, the examiner backs away about a meter, calls to the puppy while clapping, and observes whether or not the pup answers the call and how he does it. Does he comes promptly with a raised tail, seeking contact with the examiner? Does he comes promptly, with a raised 
tail, but does not make contact with the examiner? Does he comes promptly, with a lowered tail; comes hesitant, with tail down or, does not come at all and runs away? The other stages of the test are, respectively, to verify if the pup follows the examiner through space and how it does so (following with tail raised and playfully; following with wagging tail; following with lowered tail; without raising the tail; not following at all); the pup's reaction to being held down on his side (how much he struggles, bites and growls, as well as the position of his tail (wagging or lowering); his reaction to being held down on his stomach; and his reaction to being lifted off the ground (does he vigorously struggle, snarl or try to bite, or does he accept it and start to lick the hands of the examiner). The technical gestures developed by humans in this context alternate between direct and participatory actions that embrace a broad framework of gestures which will be evaluated as response to the artificial stimuli created. In the case of birds and rabbits, the animal will be chosen based upon aesthetic preferences, combined with the animal's origins with respect to its breeder's reputation.

The second step in the process of preparing the animal concerns the risk of transmission of diseases and zoonoses. For an animal to be used in zootherapy, the therapist must present documents attesting to it being free of diseases and correctly vaccinated. The application of these actions involves a vaccination plan of several doses, whose most common vaccines for dogs are designed to prevent distemper, parvovirus, kennel cough, hepatitis and leptospirosis. Worming is added to this list in order to eradicate internal parasites (worms) and doses are administered to dogs at 15 and 45 days after birth, and then every six months afterwards. Deworming of birds is usually done twice a year, a month before and immediately after the breeding period, through deworming drops that are applied to the animal's skin. With regards to rabbits, the vermifuge is marketed in liquid form and should be administered orally every four months. To avoid flea infestations, the animals should be periodically brushed and given a flea bath or treatment. The actions undertaken by humans in this context are of the external type, given the uses of additional resources (medicines, vaccines), but are also of the direct type because they directly affect the body of the animal and are internal in the case of oral administration orally or injections.

It must be remembered that the fact that an action is positively or negatively direct does not mean that it is negative for the animal or that it causes a damaging change, as is the case of a deleterious action, characterized by causing a change in the animal such as the cutting of nails, hair, ears, tail, and etc. An action is positive when the therapist reaches his goal through the animal and negative when, instead of the therapist making the animal do something, he stops it from doing something (Ferret, 2012: 126). The castration of animals, for example, is a destructive transformative action, which serves two purposes: it changes the behavior of the animal by attenuating it sexual instincts and reduces behaviors such as urinating too much, mounting other animals or people, or keeping being too aggressive. Castration as a definitive transformative act modifies the body of the animal, however, and preventing it from reproducing or entering into estrus. It is also an ambiguous action because it prevents an animal with a good temperament for zootherapy from reproducing. It is therefore a contrary action, because when man acts upon the animal in this case, he receives another action in return.

With respect to the maturation of the puppies, in Stage 3 the animals are socialized with humans and other animals from their earliest days, being stimulated to learn commands like sit, beg, talk, fetch, and play. Through exogenous actions that occur via external stimuli prompting an animal to perform an action, the socialization procedure of the young animals is begun, with therapists often working with two or three animals during a single a session. Pragmatically, the process of socialization begins by forging situations of physical interaction between the puppy, the therapist, and other people who circulate in the environment (initially, usually the therapist's home, then their workplace). The human therapists also encourage the animal to interact with the other animals in the house, in order to later insert it in therapy situations with the more experienced animals, setting the scene for exogenous and participatory type actions. At the beginning of these activities, the human therapist does not exactly know the animal's capacities. This causes uncertainty with regards to the animals' 
ability to adapt to the therapeutic activities (and raises the possibility of their withdrawal from the program), which are participatory actions. Signs of fatigue and/or stress usually indicate the end of the therapeutic session or the rejection of the animal as a zootherapist (given that the activity does not please the animal).

Step 4 involves various hygiene and aesthetic treatment techniques and includes bathing, applying perfumes, lotions, props, hair, feather, and nail trimming. Different from dogs, rabbits and birds do not need to bathe, and water and shampoo can harm them by removing the natural protections from their hair or plumage. These animals clean themselves daily, licking their hair or grooming their feathers with their beaks. When cleaning themselves, rabbits stand on their hind legs and pull their ears down with their front paws in order to attempt to lick them. As for birds, they "like to take baths" and do this both in the wild and in captivity. A bath should be made available to the animal, however, in order to let him groom himself without any hints or help. Birds' wing feathers are trimmed with scissors to prevent them from flying, modifying not only the aesthetics of the bird but also its ability to fly. The actions developed in this stage can thus be classified as direct, participatory (because birds bathe on their own when they want to), deleterious, and transformative actions.

Artifacts such as leashes, collars and harnesses are also used to manage different species of animals. Dog, birds, and rabbits can all be guided with the aid of these objects, which to a certain extent are fundamental in zootherapy in order to exercise strict control over the animal by allowing the human therapist to conduct a series of direct/positive actions that directly affect the body of the animal with the help of the tool. The human makes the animal perform actions such as standing still or moving, walking in determined directions, climbing or riding, descending, jumping or remaining in a bipedal posture resting on their hind legs. However, even though most zootheraptists make use of some sort of artefacts in the training process, there are professionals who work with free animals during their therapeutic sessions, making use of leashes only to move the animal through the public areas of health facilities, which require animals to be leashed. One of my informants during this research, the director of the Syrius Association, works with free animals (without a leash) and maintains communication through physical signs: hand signals and facial expressions. He was a canine educator and sought training in animal mediation (designation in French - Médiation Animale or Zoothérapie)s, becoming one of the pioneers in working with free animals.

The actions highlighted in Table 1 above, present a stimulated and desired behavioral panorama linked to a type of "singular" animal (to use Dominique Lestel's term ${ }^{6}$ ), but they do not allow us to objectify some of the interactions that take please between the animal and patients that take place in a scenario full of direct, deleterious, or transformative actions. However, if we look more closely at participatory and passive categories of actions, considering the way these are employed by Ferret, we can affirm that participatory actions denote voluntary actions on the part of the animal which contribute to reaching a human objective. Meanwhile passive actions demarcate the absence of human action: they allow activities to happen without humans intervening in the animal's actions. As described by Carole Ferret, these are linked to the human action of letting things take their own pace. In the scenario that I describe here, this means moments or periods in which the human let the domesticated animal act for itself. This should not be mistaken for "freedom", however, because passive action is guided by the belief that by abstaining from pushing towards a goal, this will be achieved by the "object" of the training without direct human action.

The Fondation Pierre Sommer et Adriene is responsible for regulating the profession of animal therapist in France.

Dominique Lestel has developed three levels of analysis with regards to animals. First, considering all animals as subjects in the Uexkullian sense of the term: that is, they are beings that evolve in a space of meanings, which distinguishes them from machines. Secondly, Lestel shows that some animals may become real individuals, or singularities: a leader, for example, but also any individual who presents particularities in comparison with the rest of the group. Finally, some animals tend to become people when they come in contact with humans who consider them to be such. Lestel's study dialogues with the evolution of understandings of animals in the history of philosophy. This is the starting point for an approach that Lestel calls "bi-constructivist", permitting him to defend an ethology that interprets, intervenes, innovates, and creates and allowing him to largely avoid causality, the monotony of behavioral routines and/or genetic or environmental determinism. See Lestel (2011). 
Participatory actions happen when the animal cooperates in such a way that human goals are achieved. This occurs in different contexts where animals are involved in processes such as insect control, for example. The use of the "sterile insect technique" is an internal, indirect, participatory, and contrary action. This involves the mass breeding of mosquitoes, selecting males and sterilizing them (by irradiation or genetic modification) and finally releasing them. These males, if they are large enough to compete with wild males (at least ten times as large as the wild variety), rapidly reduce the total mosquito population, because each female mosquito mates only once. Alex Nading's (2013) work describes this technique in the fight against dengue fever in Nicaragua, while Sandrine Dupé (2015) describes it in actions to control Chikungunya on Reunion Island. In the context of zootherapy we see this sort of action occurring when the animal performs with or without the therapist's demand.

Thus, when we take into account the dynamics of learning the trade of zootherapist and the importance of the personality of the animal in this, we can observe that animal behaviors associated to their needs and intentions can be classified as participatory type of action, both in those cases where the animal becomes a therapist and in those where the animal does not adapt to the dynamics of zootherapy, do not pass the personality test (i.e the Campbell Test) or does not "like" this sort of activity. According to my interviewees, "almost all animals can be used for therapy, but some animals cannot, such as those that are poisonous or those who simply do not want to be involved in the activity" (Pet Therapy and TAC, Field Registry, Porto Alegre, 2013).

Image 1: The dog is restrained by the therapist so that it stays still while the children can interact without risk to either party. This is an example of direct/interventionist action.

Apae Nova Iguaçu. Associação Pêlo Próximo.

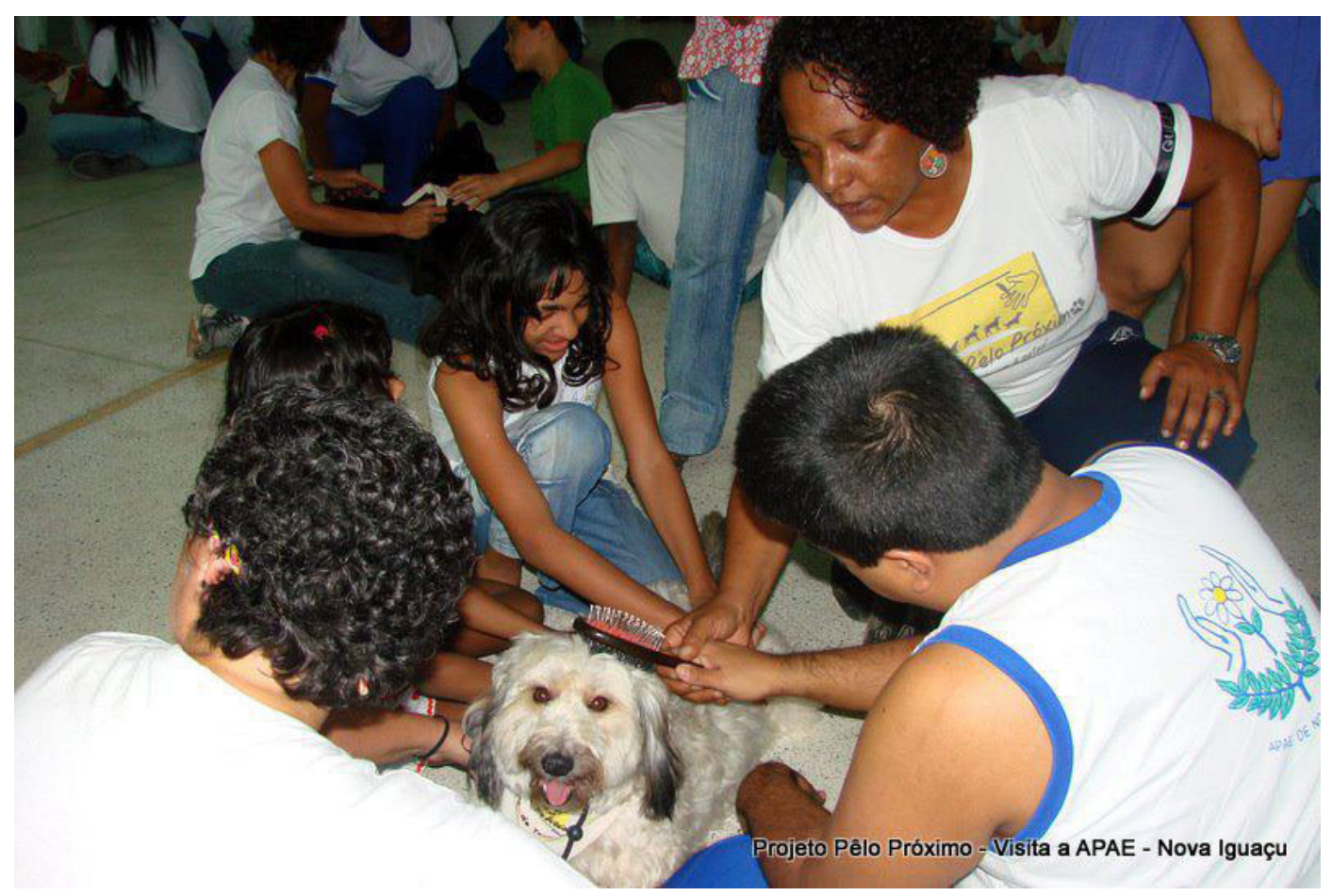

Photo: Pêlo Próximo 
Image 2: Furby the dog stays still on the table while the hoops are placed around him. A direct action that is the fruit of training and participative action in which the animal disposes itself to the activity and helps the patient by putting his head through the hoop.

La Roche-Guyon Retirement Home. Associação Cyrius Médiation Canine.

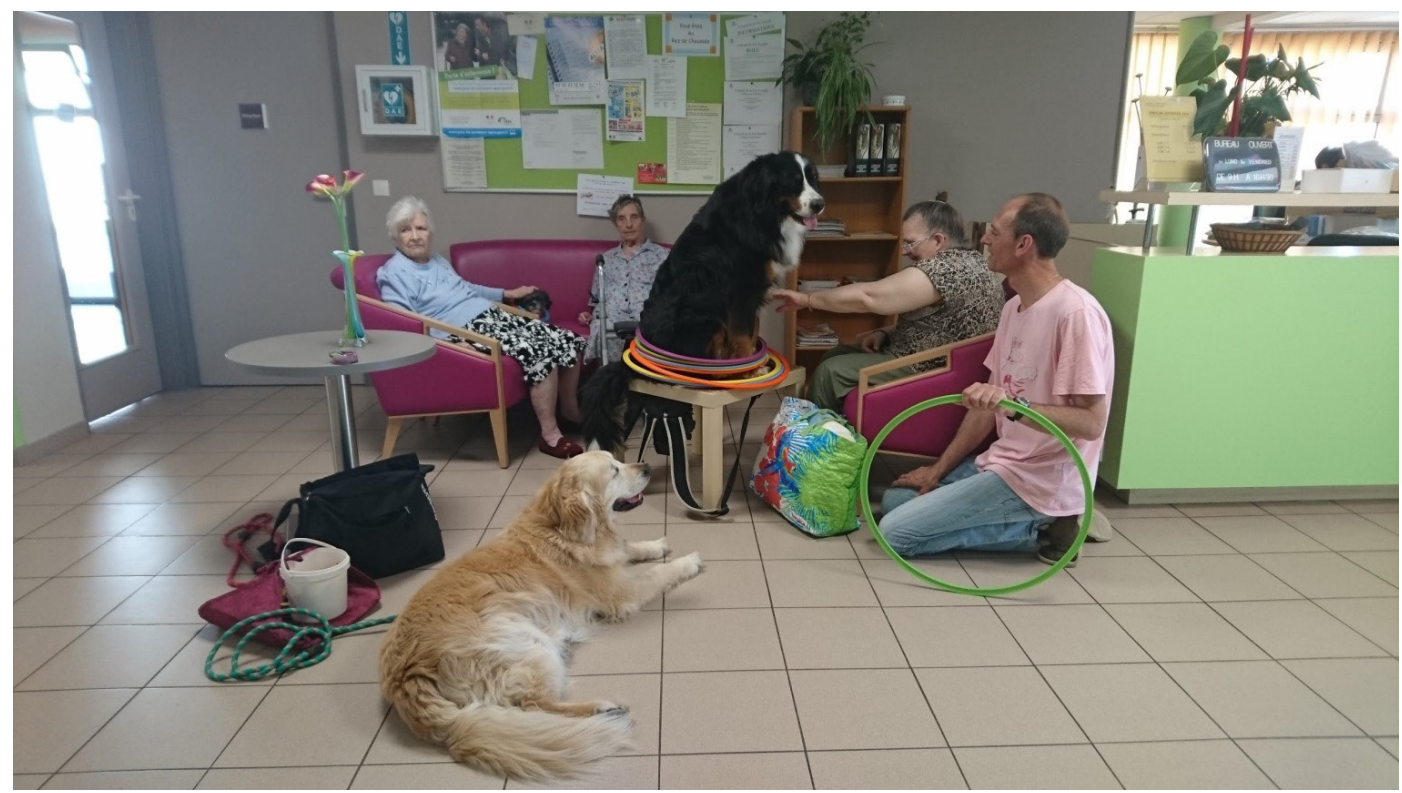

Photo: Ivana Teixeira.

Image 3: Three animals together in the same therapeutic session so that the young calopsite can be initiated into socialization with other animals, where she will learn her job through exogenous/participative action. (A censorship effect was used to blur certain parts of the image to preserve anonymity of patients.)

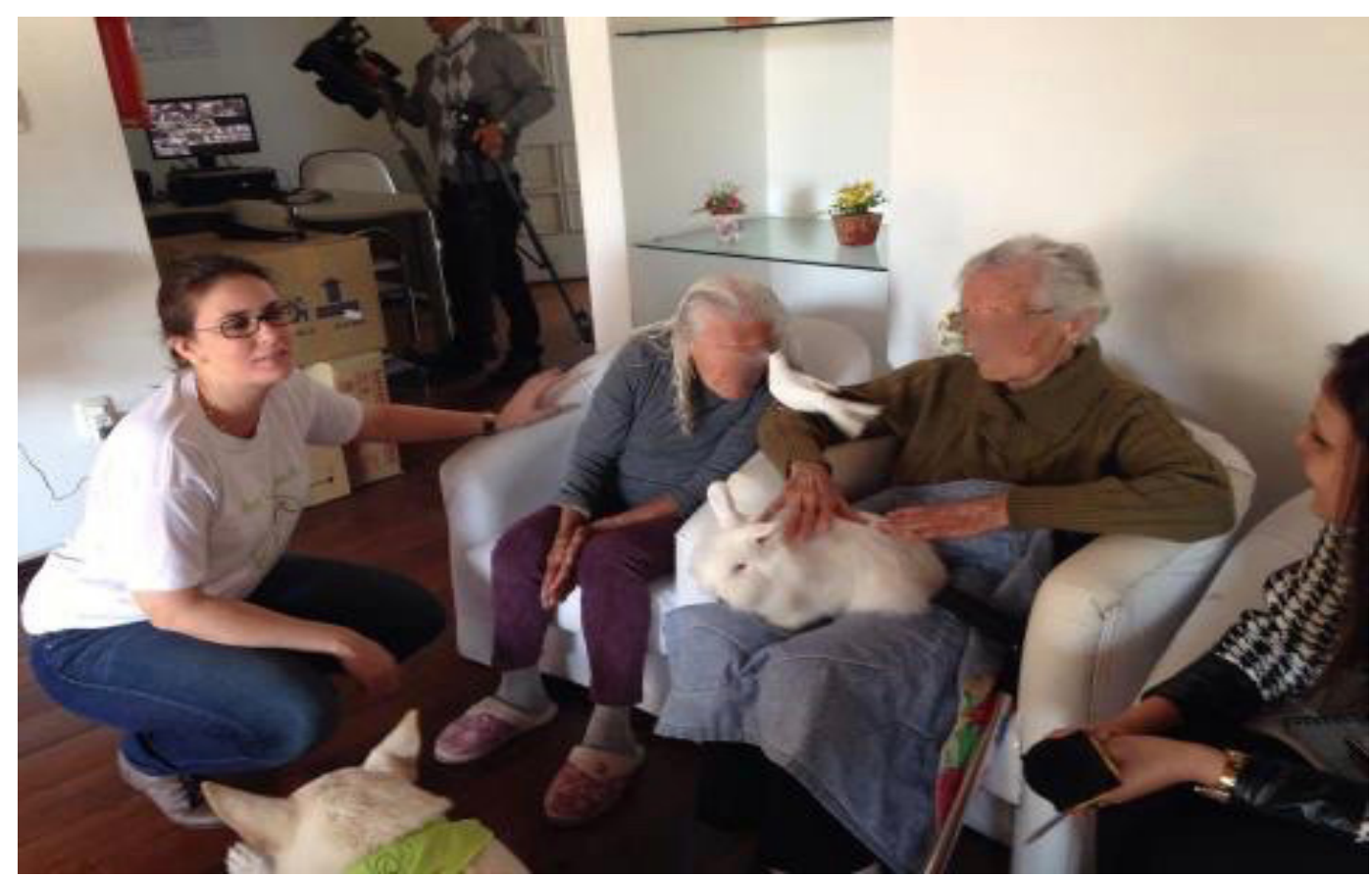

Photo: Ivana Teixeira. 


\section{The performance of non-human agents involved in the process}

If relational experience between beings is a continuous kinetics, as Tim Ingold has shown us, we must, as he teaches us, look at trajectories that are generative of other conceptual languages before seeking out the associative nodes that define humans, animals, or objects. For Ingold, the source of anthropology's difficulties in explaining such languages (or human practices of adaptation), whether rooted in the environment or culture, lies in the assumption that human relations with the environment are necessarily mediated by culture (Ingold, 2011: 76). This assertion completely excludes animals from mediation between life and environment practices. Deprived of the human capacity for symbolic representation, they are thus supposedly deprived of cultural reason. Methodologically, the process of bringing things to life would not require an effort to equip them with external agency, but rather "restores them to the generative flows of the animal world in which they exist and continue to exist" (Ingold 2011: 48).

In his article entitled "Art and Agency. An Anthropological Theory", American anthropologist Alfred Gell claims that agents initiate actions that are "caused" by themselves and by their intentions, not by the laws of physics or the cosmos (1998:16). In this case, intention is cause and action effect. Assuming that human beings are able to initiate actions in this sense, Gell believes that the organism is distributed around a series of artifacts-objects inscribed by human-originated intentions, but that these artifacts may shift from being secondary agents to primary agents and initiators of human actions. Not everyone agrees with Gell that actions are the effects of primary intentions, however, since intentionality and agency are not exactly a consequence of each other. For Ingold, the beings involved in a relation would not have agency in and of themselves: "they are rather possessed by the action ... they are swept up in the generative currents of the world" (Ingold, 2011: 214). Ingold (2000) shows that skills are present in all participants in an agentive process that becomes pragmatically objectified through a set of techniques and knowledge.

Thus in order to visualize in greater detail the process by which animal activities or engagements gain the status of agency in zootherapy, one must expose the manners in which animals do this. In zootherapy, animals have an obvious general function: they interfere with the patient's state of mind and attention through actions that lead him to produce actions, phrases, reflections, and sensations. The animal itself is supposed to produce an effect that the therapist develops. They do not remain linked to the therapist. During the session itself, it is especially important that the animal can move around. How this interaction occurs is the result of a collaboration that allows us to raise questions about the agents involved in the process and what they should be doing. Pitrou's work $(2011,2016)$ has looked at the ways in which different non-human beings are interwoven in various human processes in agricultural, political, and therapeutic contexts. His study is important for our analysis in that it shows us to objectify the different beings involved in these processes through the actions that they develop, exploring the forms of agency that they put into practice (what should they do?) and the result of their actions in humans.

Table 2, below, presents a synthesis of certain animal actions that are relevant to zootherapy and that develop in the course of therapeutic sessions, linking them to the effects they cause in humans and the meanings attributed to them by patients and therapists. 
Table 2 - Actions that animals can or should execute

\begin{tabular}{|c|c|c|}
\hline $\begin{array}{l}\text { Animal agent implied } \\
\text { in the process }\end{array}$ & $\begin{array}{l}\text { Actions that animals } \\
\text { can or should perform }\end{array}$ & $\begin{array}{l}\text { The visible effects that actions } \\
\text { produce in humans (patients) }\end{array}$ \\
\hline \multirow[t]{6}{*}{ Dog } & Lick & $\begin{array}{l}\text { Happiness at being "kissed". } \\
\text { Action: kiss the animal. }\end{array}$ \\
\hline & Bark & $\begin{array}{l}\text { Surprise, attention. } \\
\text { Action: dodge or take a step backwards. }\end{array}$ \\
\hline & Jump up on bed & $\begin{array}{l}\text { Happiness, care } \\
\text { Action: hug, kiss }\end{array}$ \\
\hline & Jump on legs & $\begin{array}{l}\text { Happiness, laughter, or surprise. } \\
\text { Action: hugs, pet fur, smell the animal; } \\
\text { feel the temerature of its body. }\end{array}$ \\
\hline & Sniff or smell & $\begin{array}{l}\text { Pleasure, tickles. } \\
\text { Action: lean back or move towards the animal }\end{array}$ \\
\hline & Lie down on side & $\begin{array}{l}\text { Action: incline the body towards or kneel } \\
\text { down to run fingers over animal's belly }\end{array}$ \\
\hline \multirow[t]{7}{*}{ Rabbit } & $\begin{array}{l}\text { Lie down on stomach } \\
\text { with body stretched out }\end{array}$ & $\begin{array}{l}\text { Calming, tranquilizing. } \\
\text { Action: poke the animal with finger or toes ("tickle" him). }\end{array}$ \\
\hline & Twich nose & $\begin{array}{l}\text { Humor, interest and curiosity. } \\
\text { Action: laughter, talk with animal }\end{array}$ \\
\hline & Move jaw from side to side & $\begin{array}{l}\text { Curiosity and pleasure } \\
\text { Action: laughter, talk with animal }\end{array}$ \\
\hline & Dig & $\begin{array}{l}\text { Curiosity and laughter. } \\
\text { Action: incline body or walk towards animal, } \\
\text { pig up animal, poke in the dirt with hand }\end{array}$ \\
\hline & Lick & $\begin{array}{l}\text { Tactical sensations and exchange of caresses. } \\
\text { Action: kiss the animal. }\end{array}$ \\
\hline & Run around person's feet & $\begin{array}{c}\text { Pleasure. } \\
\text { Action: shift body's balance. }\end{array}$ \\
\hline & Purr & Pet animal with hand. \\
\hline \multirow[t]{7}{*}{ Bird } & $\begin{array}{l}\text { Sing } \\
\text { (sounds, chirps, songs). }\end{array}$ & $\begin{array}{l}\text { Action: sing, imitate the animal, or converse } \\
\text { with the animal, attributing ideas to it. }\end{array}$ \\
\hline & Fly towards someone. & $\begin{array}{l}\text { Excitation; satisfaction (sensation of being chosen). } \\
\text { Action: dodge and then follow after the animal. }\end{array}$ \\
\hline & Lightly pick, gnaw, or nip. & $\begin{array}{l}\text { Establish a dialogue with the animal; the } \\
\text { idea that he is giving curing massage. }\end{array}$ \\
\hline & $\begin{array}{l}\text { "Caress" - lowering head } \\
\text { in order to receive a caress } \\
\text { on its neck, cheek or chest. }\end{array}$ & $\begin{array}{l}\text { Calming and tranquilizing. } \\
\text { Action: raise index finger to the animal and caress it. }\end{array}$ \\
\hline & Eat from hand & $\begin{array}{l}\text { Happiness, satisfaction, and concentration. } \\
\text { Action: hold the animal in one hand } \\
\text { and give it food from the other. }\end{array}$ \\
\hline & Urinate or defecate & $\begin{array}{l}\text { The patient considers themselves to be lucky. } \\
\text { Action: clean with hand. }\end{array}$ \\
\hline & Fluff feathers & Action: put finger in amongst animal's feathers to caress it. \\
\hline
\end{tabular}


Non-human actions thus become circumscribed in a field of intentionalities and become activators of human actions during the course of the therapeutic session. Animals must perform a range of actions and abilities that, even as they generate representations about the animal, also generate other actions in humans (Teixeira, 2016). Moreover, as we can see in Table 2, the same actions performed by different animals -- such as vocalization -- do not have the same meaning among humans. Although different species vocalize differently and this is administered/understood differently by humans (birds should sing, but dogs should not bark), vocalization has a very polyvalent role in all species, being interpreted as the anthropomorphized speech of the animals, to whom the patients respond, often singing songs like "What Does the Fox Say?", " Happy Birthday to You", or football club hymns. The grunts of animals, such as the purr of the rabbit or the noise made by the birds when they "talk softly", become triggers for real dialogues with great demonstrations of human pleasure.

More expansive actions, such as a dog jumping up on a bedridden elderly person, are stimulated in some animals (small dogs) and for some patients. Others, such as the flight of a bird towards someone, can be understood as a signal that the animal is stressed. The dog that jumps up on a patient will do it if he knows the subject with whom he interacts, provoking in most cases intense physical interaction between the two as the human hugs or holds the animal next to their body. Actions such as licking of human hands or faces (by dogs and rabbits) or nibbling at the skin or ear lobe (birds) are usually understood as a show of affection or a caress, which leads the patient to reciprocate this act by kissing or caressing the animal. In addition, smells, fur textures, skin and feathers, the shape and color of eyes, physical characteristics in general, the type of food eaten and customs display - all of this, along with other information, become characteristic of each animal, resulting in differentiated interventions by humans, who may smell the animal, rub their face or hand on it or feel its texture.

Some animal actions lead to the human action of caressing. When a rabbit stretches out its body by lying down on its belly, with its ears resting backwards, humans pass their hand along its back, caressing it. The same thing is true of a bird that tilts its head sideways and forward as if offering itself to receive affection, which it is promptly given by the patient, who passes the tip of their index finger along the animal's neck. Likewise, a dog lying in the supine position invites patients to lower themselves or crouch down, extending their arm and moving their fingers to caress the animal's belly. These actions are important, because if manipulation and physical interaction are established, the feeling of enjoyment, fun and satisfaction will be the motivation for new actions and, therefore, a continuity of the exchange. This will ensure that the animal also expresses itself more, as do birds as they walk over patients' bodies, or rabbits when they hop around patients' feet, or dogs when they place their front paws on patients' legs.

It should be borne in mind that, contrary to the idea of the animal, as object, machine, or tool, whose domestication transforms it into something "artificial", in zootherapy, the animal destined to be a therapist does not get used to the activity in many cases. The human therapist is eventually forced to look for another animal because the current one seeks to escape or avoid patients or shows irritation towards them. This, along with certain other behaviors, will be interpreted as demonstrations that the animal does not want to participate in the activity because he is tired, because he does not appreciate the environment, or for some other reason attributed to an animal's demands that is, in turn, increasingly discussed in the specific and academic context. These signs differ between the different species (in dogs: physical agitation, panting and panting, dilated pupils, lack of eye contact, yawning while looking away, among others; in rabbits: thumping with the hind leg, turning away and ignoring calls, grunting, growling, snarling, biting, kicking, running away; in birds: aggressive behavior such as bites, wheezes, lunges and excessive screams, agitation). If these behaviors are noticed in animals that already participate in zootherapy, they serve to indicate that the human therapist must bring the session to a close, according to the Delta Society (s / d: 91-92) and Chandler (2005: 60). 
The desired behavior of a therapeutic animal (neither dominant nor apathetic) indicates that the animal must withstand touch and human handling without attacking, so that the patient feels safe to proceed. What is expected of or demanded of the animal in terms of its actions implies the acquisition of skills by the animals, and includes concrete actions. As an example, let us take the ability to seek something indicated by the therapist and bring it to the patient. This is a very demanding task for dogs, often performed during zootherapeutic sessions, because it encourages the development of games between patients and the animals. There is likewise the ability to "find the treat", where the dog should choose with its paw which cup a snack is hidden under. He will then eat the snack as a reward.

It is important to point out that the acquisition of skills and knowledge ${ }^{7}$ is understood here in the context of culture, with the learning of a wide range of behaviors linked to actions, including professional techniques and all the corporality this implies. Skills are developed through a process of learning that approaches that which is densely described by Sautchuk (2015) regarding the processes of the construction of the personhood of coastal and lake fishermen in the Amazon estuary. In both cases, abilities result from a conjunction of movements. Skills enable the animal to relate to other people, to appropriate space, to understand and to interfere in the scenario in which it finds itself. Table 3 shows some of the most recurring abilities in the zootherapy sessions, from a positive point of view according to Haudricourt (1962). In other words, these are seen as things that contribute to human goal being achieved.

Table 3 - Animal Agent Abilities

\begin{tabular}{|c|c|c|}
\hline $\begin{array}{l}\text { Animal agent } \\
\text { involved in } \\
\text { process }\end{array}$ & Ability that animal can or should perform & $\begin{array}{l}\text { Effects - visible actions that animals } \\
\text { produce in humans (patients) }\end{array}$ \\
\hline \multirow[t]{4}{*}{ Dog } & $\begin{array}{l}\text { Demand or desire the patient's attention. } \\
\text { Action: look at patient, place front paws } \\
\text { on patient's knee, jump up on patient. }\end{array}$ & $\begin{array}{l}\text { Take animal in arms or touch } \\
\text { animal's face with hand. }\end{array}$ \\
\hline & Silence (lack of barking or growling). & $\begin{array}{c}\text { Talk with animal and expressing comments } \\
\text { as if these came from the animal. }\end{array}$ \\
\hline & $\begin{array}{l}\text { Control physiological needs of } \\
\text { express these in an area outside of } \\
\text { the work environment (lawn). }\end{array}$ & $\begin{array}{l}\text { Perceive animal as a well-trained living being, } \\
\text { prepared, apt, and acting appropriately. }\end{array}$ \\
\hline & $\begin{array}{l}\text { Execute training. } \\
\text { Action: search out objects } \\
\text { Action: find the treat }\end{array}$ & $\begin{array}{l}\text { Happiness, smiles, satisfaction, enchantment. } \\
\text { Action: clap hands, pet animal, emit } \\
\text { words to encourage the dog. }\end{array}$ \\
\hline \multirow[t]{3}{*}{ Rabbit } & Exhibit exuberant plumage & $\begin{array}{l}\text { Fascination, curiosity and desire. } \\
\text { Action: touch animal with hand. }\end{array}$ \\
\hline & $\begin{array}{l}\text { Control physiological needs of } \\
\text { express these in an area outside of } \\
\text { the work environment (lawn). }\end{array}$ & $\begin{array}{l}\text { Perceive animal as a well-trained living being, } \\
\text { prepared, apt, and acting appropriately. }\end{array}$ \\
\hline & Accept being held & $\begin{array}{l}\text { Action: hold animal in arms or } \\
\text { lift it up on its hind legs. }\end{array}$ \\
\hline
\end{tabular}

7 The "cultural" abilities of human beings are constituted within a enskilment proces and "this leads me to conclude that in the growth of human knowledge the contribution that each generation makes to the next is not an accumulated supply of representations but an education of attention" (Ingold 2010, p. 7). 


\begin{tabular}{|c|c|c|}
\hline Bird & Pirch on shoulder or other part of the body. & $\begin{array}{c}\text { Action: stay still with the animal } \\
\text { perched on oneself. }\end{array}$ \\
\cline { 2 - 3 } & $\begin{array}{c}\text { Learn a song such as a football club } \\
\text { hymn or "Happy Birthday" }\end{array}$ & $\begin{array}{c}\text { Fascination and contentment. } \\
\text { Action: sing or whistle the song. }\end{array}$ \\
\cline { 2 - 3 } $\begin{array}{c}\text { Hop along patient's arm, perch on } \\
\text { patient's shouler, or hop down the other } \\
\text { arm, moving across patient's torso }\end{array}$ & $\begin{array}{c}\text { Feeling of being tickled. } \\
\text { Action: extend arm out and hold it there. }\end{array}$ \\
\hline
\end{tabular}

Based on the above table, we can see that zootherapy operates through sensory, physical, and emotional exchanges that are closely linked to interactions between humans and animals and to their psychological states. While the sequence of exchanges between man and animal is complex, the human responses will be according to their experiences and in line with what we see in Table 3 above. Many health professionals research and write about these effects ${ }^{8}$, as can be seen in the studies conducted by Levinson (1969), Silveira (1982) and Schutz (2012). The psychological effects of this therapy include changes in patients' perception, demonstrations of happiness, and emotions attributable to anticipation of the animal's visits (Fine, 2010). One benefit often reported in both child and adult patients is that of relief or distraction from psychic distress (Serpell, 2010). With regards to social effects, the animal acts as a communication bridge, allowing the patient to connect with and change the outside world (Levinson, 1969; Silveira, 1998; Halm, 2008). As far as physiological effects are concerned, the movements that zootherapy promotes are of a different order, because they cause changes in the levels of certain physiological elements that are considered beneficial to human health, such as enzymes, neurotransmitters, and hormones which, in the long run, transform the state of mind and health of the patient. Mendelson and Baggot (2007) reported changes in oxytocin levels (responsible for, among other things, provoking feelings of empathy, pleasure, and fear), with concentrations doubled after interaction between humans and animals. These researchers also report decreasing blood pressure and cortisol levels in humans. Nepps et al. (2014) conducted a one-year study in which a total of 214 patients admitted to the psychiatric unit of Lancaster General Hospital were evaluated regarding the effects of a zootherapy program according to psychological and physiological variables such as symptoms of depression and anxiety, as well as blood pressure, pulse, salivary cortisol and pain. After participating in the animal-assisted activity, patients showed significant improvement in psychological and physiological indicators such as reduction of signs of depression, anxiety, pain, and pulse rate. These findings are consistent with equivalent reductions in anxiety found by Barker (2005), who investigated the optimal time to measure stress and immune function effects after interaction with a therapy dog in twenty-one subjects in a hospital setting. The concentrations of cortisol, epinephrine, norepinephrine, and lymphocytes collected at the beginning of the session were evaluated. Analysis indicated significant reductions in serum and salivary cortisol, whose peak of reduction appeared within minutes after interaction with a dog.

8 One of the best-known scholars in this field is Boris Levinson, a child psychiatrist who, from the 196os on, theorized regarding the use of animals to treat emotional disorders in autistic children. Levinson worked with dogs (Jingle was his first animal therapist) and conducted a one-year study that showed that patients living in an infirmary where pets were present consumed half of the medication of a control group in an animal-free ward (Levinson, 1969). For Levinson, the animal's role in the healing process can be traced to the "transitional object" that Winnicott (1975) refers to: objects that appear to be soft, cute artifacts such as teddy bears given to children between the ages of 4 and 12 months. According to Levinson: "contact with the inanimate and particularly the animate world via the pets is most important to whole-some emotional development" (Levinson, 1969: 12). In the 1980s, psychiatrist Nise da Silveira described the development of zootherapeutic activities at the Pedro II Psychiatric Hospital in Rio de Janeiro, stating that a partnership of one of her patients with the dog Wolf "led to a calm perennial psychic reorganization, as [the patient] indicated that some of Wolf's actions were related to his ghosts "(Nise da Silveira, 1982). The study by Alexandre Monteiro et al. (2012), one of the interlocutors of the present research, carried out in the dependencies of a clinic in Rio de Janeiro specializing in the treatment of Alzheimer's cases through, shows that weekly sessions over a period of more than four months are associated with partial recovery of memory, reduction of levels of aggressiveness, and cognitive rehabilitation in people suffering from Alzheimer's disease (Monteiro et al, 2012). 
Image 4 - Two therapy dogs, Furby and Elko, lay on patients who pet them or simply smell them and feel the texture of their fur in a demonstration of participative action.

Hospital de La Roche-Guyon, Associação Syrius Mediation Canine.

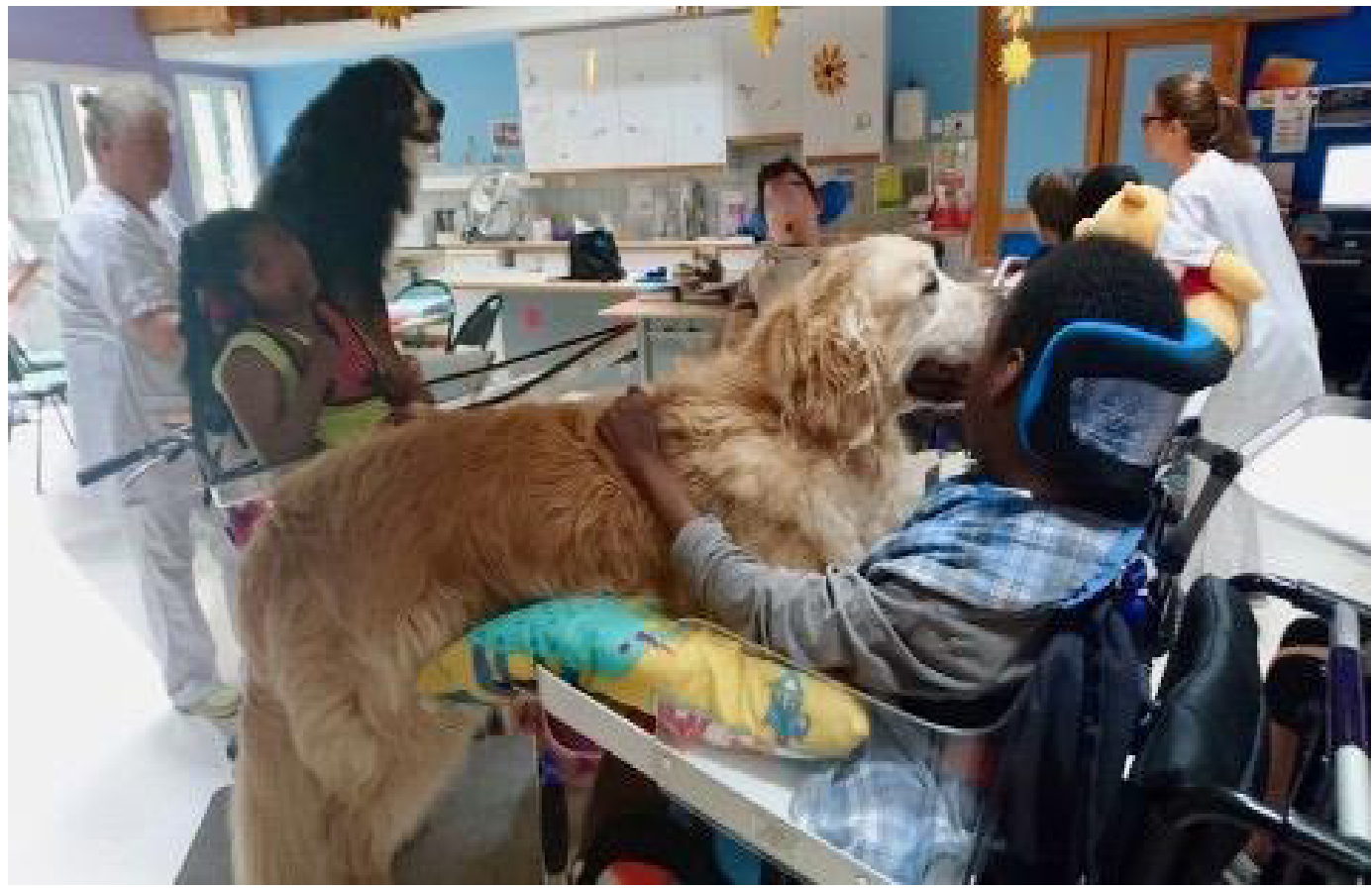

Photo: Ivana Teixeira.

Image 5: The dog Faith lies down on her side, turned towards a lady who places her hand between her paws in an example of passive/participative action. Residencial Terapêutico, Associação Pet Terapia.

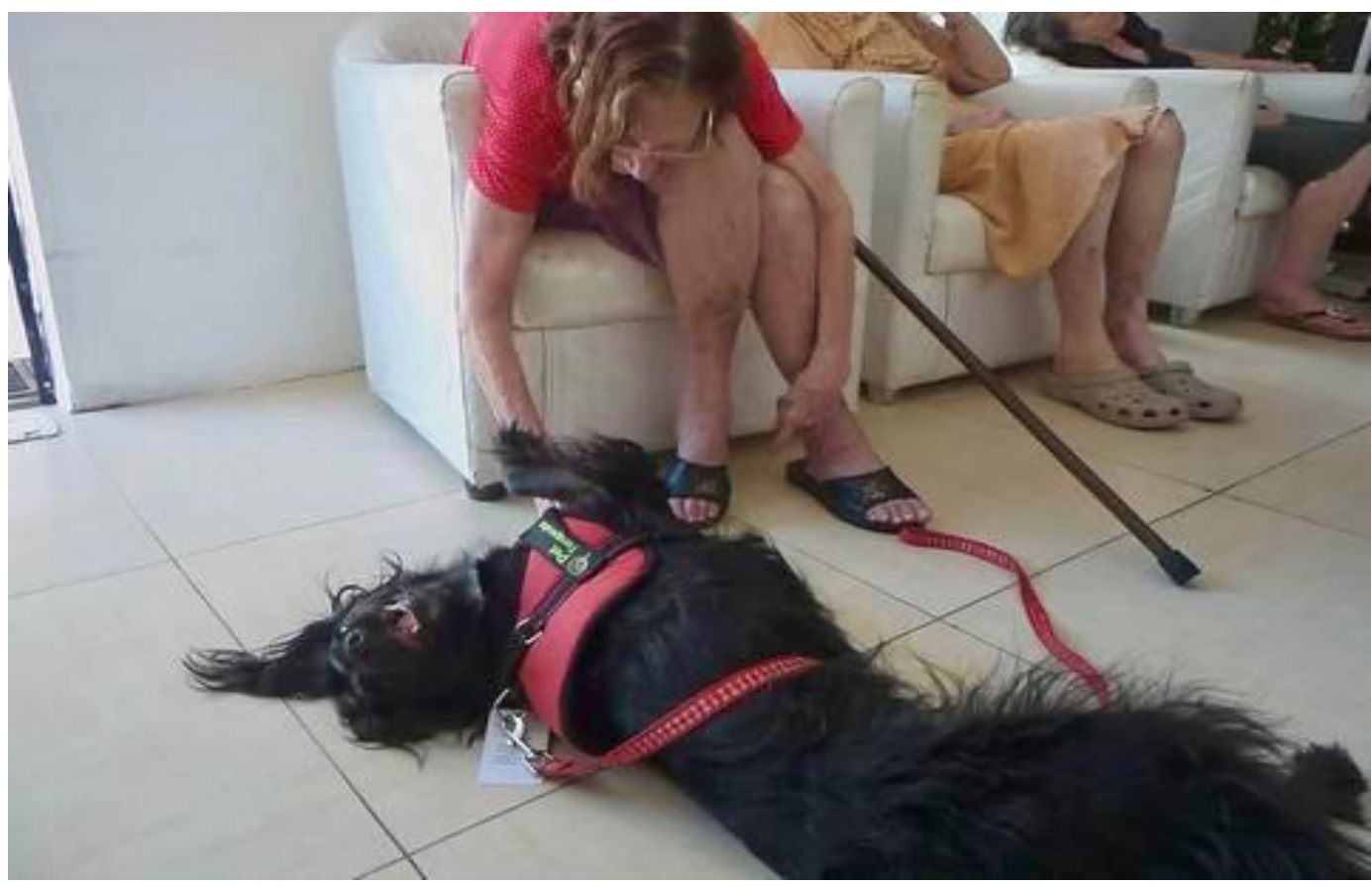

Photo: Ivana Teixeira. 
Image 6: Child and the dog Lira lay together and play, without input from the human therapist, in an example of passive/participative a ction.Hospital de Clínicas de São Paulo. Associação TAC- Terapia Assistida por Cães.

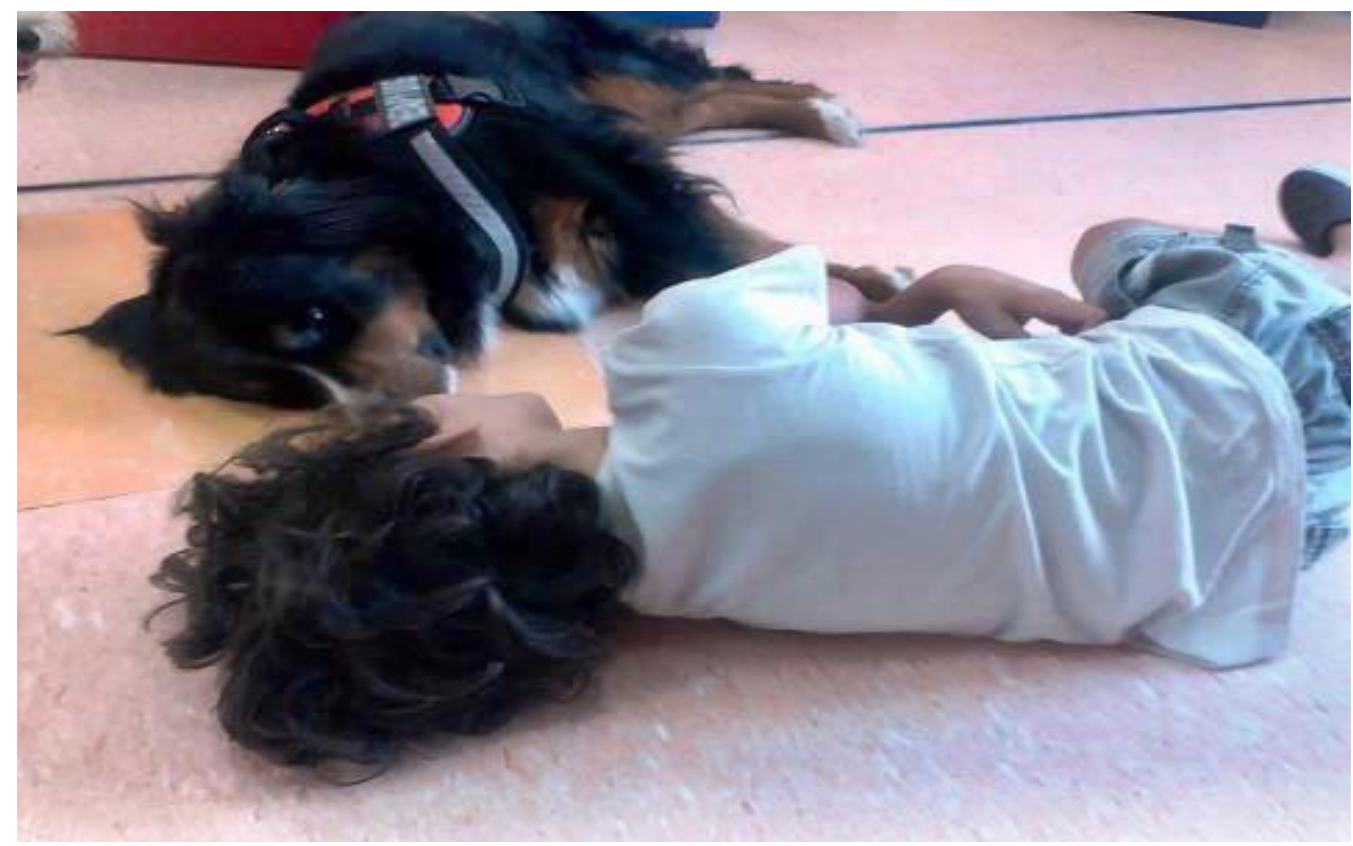

Photo: TAC.

Image 7: Ozzy the calopsite tilts his head so that a lady can extend her hand and pet him. Associação Pet Terapia.

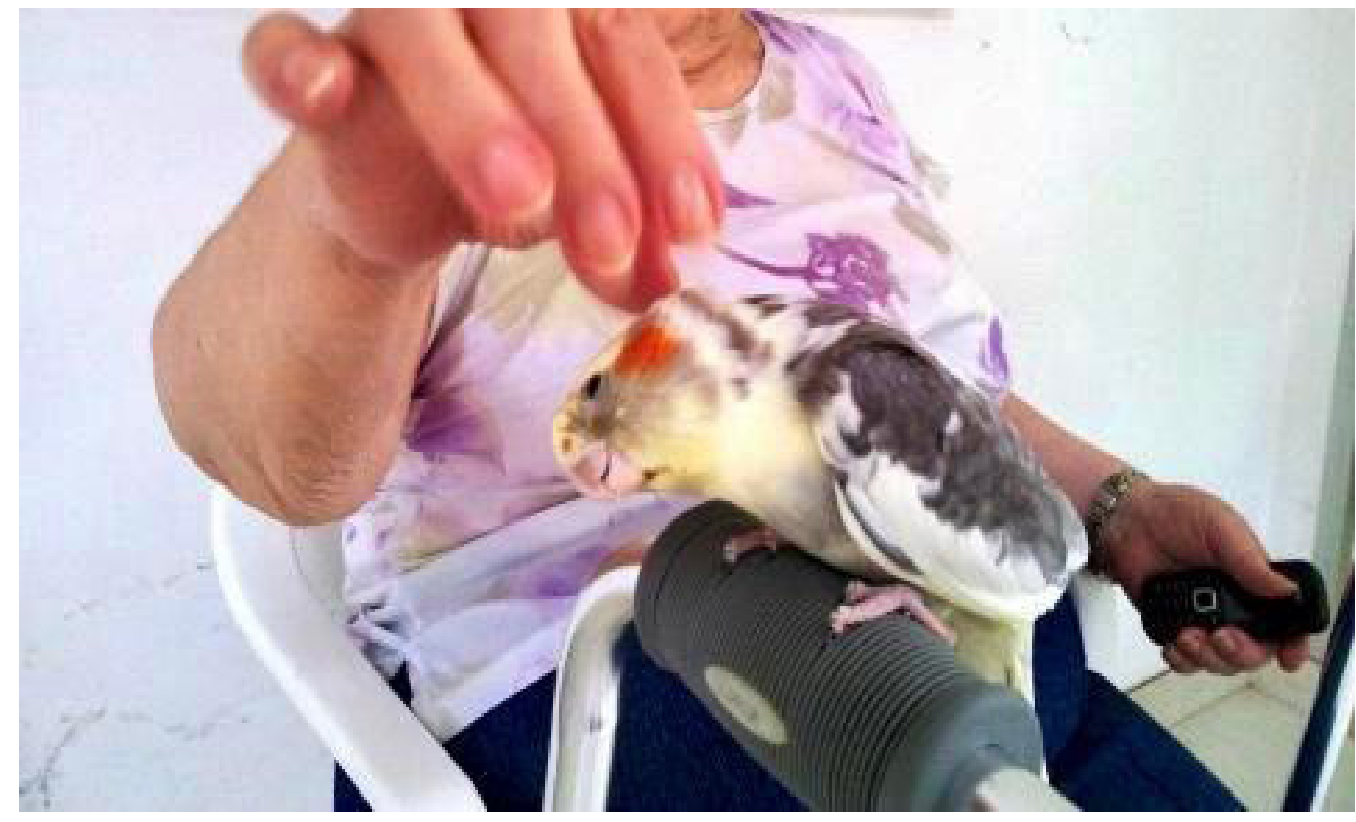

Photo: PetTerapia. 


\section{Final considerations}

In affirming the therapeutic character of contact with animals, zootherapy presumes that interspecific relational experiences can provoke psychological, psychic, social, and physiological recovery. Zootherapy also indicates that by experiencing different types of "ecological" relationships, human beings can regain sensations they have lost or have poorly developed in their social context. These perceived recoveries or effects in humans, centered on interactions with animals, demonstrate restitution of physical, social, and affective dimensions using a kind of analogy of interiorities and an exchange of gestures. In general, animal mediation works with attributes as a kind of relational complementarity, allowing for reciprocal cooperative exchanges or mutual production, according to Ingold (2000: 52). In this relationship the animal emerges from a position as object to one of subject of communication and intervention because, being signified with therapeutic capacities, it also becomes transformative agent.

There is an alternation of roles in the course of the therapeutic session, because human and animal switch off to one another in their roles as mediator. The human therapist will mediate the interaction of the animal with the intention of exploring the fruits of the developing relationship between it and the human. At a more or less constant pace, passive (human) actions are enacted, allowing the animals to develop this relationship (Ferret, 2014, 1012), offering them space to do so. Here, we have the active and participative actions of the animals, that are subdivided and expressed in the diverse movements exchanged with the patients. Motivated by the actions of the animal, both human therapists and patients make use of body techniques that lead to health and well-being, relating to the (inter)actions provided by animals that, despite being trained for this task, demonstrate a particular pre- associated with the animal's character. With this as our background, we can question to what extent these same practices allow us to identify a pedagogical dimension that is expressed in the learning of a way of looking at and perceiving oneself and the animal, constituting what we could call a new ethos that changes the way humans see animals. These competencies are acquired, as shown in Table 1, through the standardization of therapeutic techniques in formal health institutions (professionalization courses, bibliographic production, scientific research, etc.), as well as in informal instances (in the family, with groups of other animals) which are inscribed in differing ways in different environments and spaces.

Zootherapy establishes a specific relation in its environment because the hierarchy of the animals seems not to be based on the biological evolution of beings or on human characteristics, but on the variations in the modes of communication between them that allows an expression of sensitivities and qualities that are differently distributed in the diverse species that act in zootherapeutic practice. These can be observed in the interaction between species because there exists a predisposition in both parties, human and animal, to communicate by establishing quiet offerings and psychic organization. This allows us to point out that, although the agency of nonhumans has a special place in naturalist ontologies, field data shows that, in the context of live animal therapy, actions exchanged between animals, patients and therapists do not develop solely from the driving motor of human action.

Received: July 15, 2018

Accepted: July 03, 2019

Translation by Thaddeus Gregory Blanchette 


\section{Bibliography}

ALVES, R. R. N.; DIAS, T. L. P. 2019. "Usos de invertebrados na medicina popular no Brasil e suas implicações para conservação”. Tropical Conservation Science, 3 (2):159-174.

ARAÚJO, A. M. 1977. Medicina Rústica. São Paulo: Companhia Editora Nacional.

BECHELANY, Fabiano C. 2013. "HAUDRICOURT, André-Georges. Des gestes aux techniques : Essai sur les techniques dans les sociétés pré-machinistes ». Anuário Antropológico [Online], II | 2012, consulted: July 03, 2017. URL : http:/|journals.openedition.org/aa/233

BARKER, Dawson. 2005. "The effects of animal-assisted therapy on anxiety ratings of hospitalized psychiatric patients". Psychiatric Service, 49: 797-80.

CAMPBELL, W. E. 1972. “A behavior test for puppy selection”. Modern Veterinary Practice, 53(12): 29-33.

CHANDLER, Cynthia K. 2005. Animal Assisted therapy in counseling. 2a ed. New York: Routledge.

COSTA-NETO, E.M. 1999. "Healing with animals in Feira de Santana city, Bahia, Brazil". Journal of Ethnopharmacology 65: 225-230.

DELTA SOCIETY. www.petpartners.org, $s / \mathrm{d}$.

DIXIT, AK; KADAVUL, K; RAJALAKSHIMI, S; SHEKHAWAT, MS. 2010. Ethno-medico-biological studies of South India. Indian Journal of Traditional Knowledge. 9 (1):116-118.

DUPÉ, S. 2015. Separer les moustiques des humains a la Reunion. Co-production d'un nouvel ordre socio-naturel en contexte post-colonial. Thèse de doctorat, Musée d'Histoire Natural, Paris.

FERRET, Carole. 2006. Techniques iakoutes aux confins de la civilization altaïque du cheval. Contribution à une anthropologie de l'action. Thèse de doctorat en anthropologie sociale et ethnologie, EHESS, Paris. . 2012. "Vers une anthropologie de l'action. André-Georges Haudricourt et l'efficacité technique».

L'Homme, 202: 113-140.

. 2014. "Towards an anthropology of action: From pastoral techniques to modes of action". Journal of Material Culture, 19(3): 279-302.

FINE, Aubrey H. 2010. Handbook on Animal - Assisted Therapy. Theoretical Foundations and Guidelines for Practice. $3^{\mathrm{a}}$ Edição. London: Academic Press/Elsevier.

GALHARDO, D. A.; FACCIO, N. B.; LUZ, J. A. 2015. O conceito antropológico de cadeia operatória, sua aplicação e contribuição no estudo de artefatos líticos arqueológicos. Cadernos do LEPAARQ(on line) Vol. XII, $\mathrm{n}^{\circ} 23$.

GELL, Alfred. 1998. Art and agency: an anthropological theory. Oxford: Clarendon.

HALM, Margo A. 2008. “The Healing Power of the Human-Animal Connection”. American Journal of Critical Care, $17(4): 372-376$.

HAUDRICOURT, A-G. 1962. " Domestication des animaux, culture des plantes et traitement d'autrui ». L'Homme, 2(1): 40-50. . 1964. « Nature et culture dans la civilisation de l'igname : l'origine des clones et des clans ».

L'Homme, 4(1) : 93-104.

. 1969. Domestication of animals, cultivation of plants and human relations. Information (International Social Science Council), 8(3), 163-172. https://doi.org/10.1177/053901846900800310 . 1987. La technologie science humaine. Recherches d'histoire et d'ethnologie des techniques, Paris, éd. de la Maison des Sciences de l'Homme.

INGOLD, T. 2000. The Perception of the Environment: essays in livelihood, dwelling and skill. London: Routledge. . 2010. From the transmission of representations to the education of attention. Educação, Porto Alegre, v. 33, n. 1, p. 6-25, jan./abr. 
2011. Being Alive. London: Routledge.

KANG, S., and PHIPPS, M. 2003. A Question of Attitude: South Korea's Traditional Medicine Practitioners and Wildlife Conservation. TRAFFIC East Asia, Hong Kong.

KOHN, E. « Como os cães sonham ", Ponto Urbe [Online], 19 | 2016, posto online no dia 31 Dezembro 2016, consultado o o9 Janeiro 2017. URL : http://pontourbe.revues.org/3326 ; DOI : 10.400o/pontourbe.3326 LESTEL, D. 2004. L'Animal singulier. Seuil: Paris. . 2011. "What Capabilities for the Animal ?" Biosemiotics, 4(1): 83-102. DOI: 10.1007 / s12304-010-9109-6. LEVINSON, Boris. 1969. Pet Oriented Child Psychotherapy., publisher. Springfield, Illinois: Charles C. Thomas. LEROI-GOURHAN, André. 1964. Le Geste et la Parole I. Technique et Langage. Paris: Albin Michel. MANCHKOUR-M'RABET, S.; HÉNAUT, Y.; WINTERTON, P.. ROJO, R. 2011. "A case of zootherapy with the tarantula Brachypelma vagans Ausserer in traditional medicine of the Chol Mayan ethnic group in Mexico". Journal of Ethnobiology and Ethnomedicine, 7:12. http://www.ethnobiomed.com/content/7/1/12. MAUSS, Marcel. 2003. Sociologia e antropologia. São Paulo: Cosac \& Naify.

MENDELSON, J.; BAGGOT, M. 2007. “Love: a chemical connection. Is there a pharmacology of love?” San Francisco Medicine, 8o(6): 10-15.

MOHAWAR, M.; JAROLI, DP. 2008. “Traditional zootherapeutic studies in India: a review.” Journal of Ethnobiology and Ethnomedicine, 4:17. http://www.ethnobiomed.com/content/4/1/17

MONTEIRO, Alexandre M. F. 2012. O uso da Terapia Assistida por Animais para a redução de alterações de comportamento na doença de Alzheimer. Disponível em: http://www.centronati.com/ ousodaterapiaassistidaporanimaisparaareducao

NADING, A. 2013. "Humans, Animals, and Health: From Ecology to Entanglement". Environment and Society: Advances in Research 4: 60-78, Berghahn Books.

MUSSOLINI, Gioconda. 1946. "Os Meios de Defesa contra a Moléstia e a Morte em Duas Tribos Brasileiras: Kaingang de Duque de Caxias e Bororo Oriental”. Revista do Arquivo Municipal, 110:7-152.

NEPPS, P; STEWART, C.; BRUCKNO, S. 2014. "Animal-Assisted Activity: Effects of a Complementary Intervention Program on Psychological and Physiological Variables". Journal of Evidence-Based Complementary \& Alternative Medicine, 19(3): 211-215.

PITROU, P. 2011. "El papel de 'Aquel que hace vivir' en las prácticas sacrificiales de la Sierra Mixe de Oaxaca”. In: Perig Pitrou, Johannes Neurath and María del Carmen Valverde (eds.), La noción de vida en Mesoamérica. México: CEMCA-UNAM. pp. 119-154.

PITROU, P. 2016. « Action rituelle, mythe, figuration. L'imbrication des processus vitaux et des processus techniques en Mésoamérique et dans les Basses-Terres d’Amérique du Sud ». Revista de antropologia, Introduction du numéro spécial, 59(1): 6-32.

SAUTCHUK, Carlos E. 2015. "Aprendizagem como gênese: prática, skill e individuação”. Horizontes Antropológicos, ano 21, 44: 109-139.

SERPELL James. 2010. "Animal-assisted interventions in historical perspective". In: Aubrey H. Fine (org.), Handbook on Animal- Assisted Therapy: Theoretical Foundations and Guidelines for Practice. $3^{\text {rd }}$ edition. San Diego, CA, USA: Academic Press is an imprint of Elsevier.

SCHUTZ, Karina. 2012. Terapia Assistida por Animais aplicada à Terapia CognitivoComportamental. Monografia de Especialização em Psicoterapia Cognitivo Comportamental, PUCRS, Porto Alegre.

SILVEIRA, Nise da. 1982. Imagens do inconsciente. Rio de Janeiro: Alhambra. . 1998. Gatos, a Emoção de Lidar. Rio de Janeiro: Léo Christiano Editorial.

SOEWU, D.A. 2013. "Zootherapy and Biodiversity Conservation in Nigeria”. In: Alves R., Rosa I. (eds) Animals in Traditional Folk Medicine. Springer, Berlin, Heidelberg. 
TEIXEIRA, I. S. 2016. "Relações interespecíficas de cuidado no sistema de saúde convencional brasileiro: uma análise antropológica sobre a dinâmica da zootherapy”. Iluminuras, 17: 390-424.

WINNICOTT, D. W. 1975. Objetos transicionais e fenômenos transicionais. In D. W. Winnicott, O brincar e a realidade (J. O. A. Abreu \& V. Nobre, Trads.). Rio de Janeiro: Imago. (Original publicado em 1953)

\section{Ivana Teixeira}

Doctor of Social Anthropology, UFRGS, Post-Doctorate in Collective Health from UFRGS

https://orcid.org/0000-0002-6409-7820

18, rue du Général Leclerc, 93370, Montfermeil, França

Phone: +330623980305

Author's e-mail: ivanasteixeira@gmail.com 